BIP: Jurnal Bahasa Indonesia Prima

Vol. 3, No. 2, 2021, September 2021, PP.

\title{
PENINGKATAN KEMAMPUAN MENULIS PUISI LAMA DENGAN MENGGUNAKAN MEDIA AUDIO VISUAL SISWA KELAS VIII-1 SMP PANGERAN ANTASARI
}

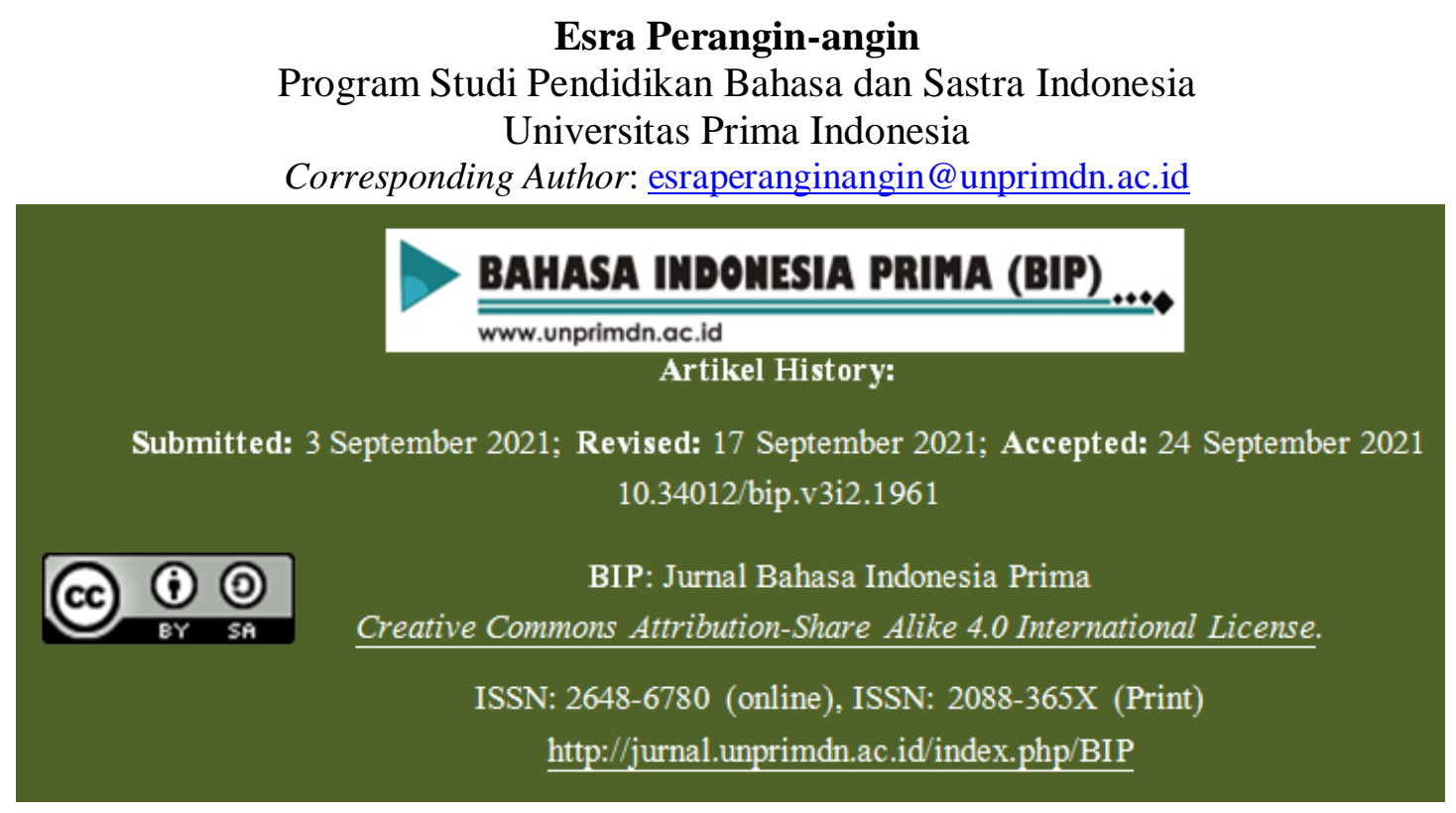

Abstrak-Tujuan penelitian ini adalah untuk mengetahui kualitas proses kemampuan menulis puisi lama siswa, untuk mengetahui dan menjelaskan kualitas hasil kemampuan menulis puisi lama siswa menggunakan media audio visual di kelas VIII-1, dan untuk mengetahui dan menjelaskan peningkatan kemampuan menulis puisi lama di kelas VIII-1 SMP Pangeran Antasari menggunakan media audio visual Tahun Pembelajaran 2016/2017. Data penelitian ini adalah data deskriptif dan data kuatitatif, yang berupa hasil menulis puisi lama siswa, nilai menulis puisi lama siswa, observasi, angket serta dokumentasi secara tertulis lainnya seperti silabus, RPP, dan materi pembelajaran menulis puisi lama dengan menggunakan media audio visual. Nilai prasiklus mencapai 33.6\% dan hanya satu siswa yang mencapai nilai KKM atau sebesar $4 \%$. Karena belum ada tindakan dalam penelitian prasiklus, pada siklus I mencapai $64,3 \%$ dan terdapat tujuh siswa yang mencapai nilai KKM dengan persentase sebesar $28 \%$. Keadaan tersebut disebabkan karena siswa banyak mengalami kesulitan dalam pemilihan kata yang tepat untuk menulis puisi lama. Pada siklus II siswa mengalami peningkatan rata-rata mencapai $82.68 \%$ yaitu terdapat 23 siswa yang mencapai nilai KKM dan melampaui dari KKM dengan persentase $92 \%$. Terjadi peningkatan sebanyak $22.23 \%$.Hal tersebut terjadi karena pada saat kegiatan pembelajaran peneliti memberikan pembelajaran semakin intensif sehingga pembelajaran menyenangkan dan tidak membosankan.Nilai ketuntasan belajar klasikal pada siklus II mencapai $92 \%$ atau dalam kategori sangat baik.

Kata kunci: peningkatan, menulis, puisi, lama

\section{A. Pendahuluan}

Karya sastra pada dasarnya menceritakan kenyataan hidup dalam bentuk artistik sehingga kehadirannya mempunyai arti tersendiri bagi pembaca atau penikmatnya. Karya sastra memberikan sumbangan terhadap pencerdasan kehidupan manusia untuk membantu manusia menjadi makhuk yang simpatik, pemikir, dan berbudaya. Melalui karya sastra manusia dapat belajar tentang hubungan sesama manusia dan persoalanpersoalan manusia. Puisi sebagai karya 
satra tidaklah terlepas dari masalah kehidupan.

Dalam puisi masalah kehidupan dan kemanusiaan yang dikemukakan biasanya tidak terlepas dari aspek-aspek sosial masyarakat dalam hubungan manusia dengan manusia lainnya. Puisi juga mampu merangsang manusia untuk menghayati sebuah kehidupan, sebab peristiwa demi peristiwa yang dimunculkan oleh pengarang dalam karya sastra puisi secara tidak langsung akan memberikan pembelajaran nilai-nilai moral yang dapat memunculkan kepekaan seseorang terhadap nilai-nilai kehidupan di sekitar manusia.

Seperti halnya novel dan drama, puisi sebagai karya sastra perlu diapresiasikan lewat pembacaan terhadap teksnya yaitu melalui penulisan puisi. Puisi sebagai karya sastra merupakan hal yang utama untuk didekati, dipahami, ditelaah, dan diapresiasi. Dari pengapresiasian teks yang dilakukan maka akan diperoleh pengalaman. Pengalaman inilah yang akhirnya kita hubungkan dengan keadaan sebenarnya di kehidupan nyata. Akhirnya ditemukanlah suatu perubahan nilai-nilai dalam diri seseorang. Peranan puisi sebagai penyeimbang kehidupan manusia menjadikan pembelajaran menulis puisi penting diberikan dalam proses pendidikan. Melalui pembelajaran menulis puisi, siswa diharapkan mampu memetik pengalaman tentang kehidupan yang dituangkan dalam teks-teks puisi karena pada dasarnya teks puisi merupakan hasil penciptaan dan perenungan terhadap nilainilai kehidupan. Oleh sebab itu pembelajaran puisi diberikan dari jenjang Sekolah Dasar (SD), Sekolah Menengah Pertama (SMP) sampai Sekolah Menengah Atas (SMA) untuk mengasah kemampuan siswa dalam memahami pikiran, perasaan, dan pendapat yang ingin disampaikan orang lain melalui karya sastra.

Pembelajaran menulis puisi, sebagai bagian integral pembelajaran sastra memiliki tujuan untuk mempertajam perasaan, penalaran, daya imajinasi, kepekaan terhadap masyarakat, budaya, dan lingkungan hidup. Secara komprehensif pembelajaran puisi dapat memberikan kontribusi positif dalam pembelajaran moral, sikap, watak, budi pekerti, pengetahuan budaya, dan keterampilan berbahasa. Dalam konteks ini dapat dinyatakan bahwa pembelajaraan puisi yang didasarkan pada paradigma dan orientasi baru implementasinya bertumpu pada kegiatan yang bersifat reseptif, kreatif, dan produktif untuk menggali, mengenali berbagai macam nilai. Serta mengungkapkannya secara tertulis diyakini dapat membentuk pribadi pembelajar yang berkarakter. Keterampilan menulis puisi merupakan aktivitas belajar yang bersifat produktifkreatif. Artinya, pembelajaran dilakukan agar siswa mampu memproduksi karya dalam bentuk puisi dan memanfaatkannya dalam kehidupan sehari-hari. untuk sampai kepada proses memproduksi puisi diperlukan sebuah proses kreatif.

Pada umumnya pembelajaran menulis puisi di sekolah masih belum berjalan secara optimal. Pembelajaran menulis puisi merupakan kegiatan belajar yang bersifat produktif. Berdasarkan wawancara dan studi pendahuluan yang pernah dilakukan dengan guru dan murid kelas VIII-1 setiap tahunnya mendapat nilai yang berbeda-beda, diketahui dari tahun pembelajaran 2013/2014 nilai rata-rata kelas VIII-1 adalah 50, 2014/2015 adalah 50, dan 2015/2016 adalah 60. Dari data yang terlihat tersebut, terlihat sangat jelas bahwa nilai rata-rata dalam kemampuan 
menulis puisi pada siswa kelas VIII-1 dalam tahun pelajaran yang berbeda-beda, masih sangat rendah dari nilai KKM yang telah ditentukan oleh sekolah Swasta Pangeran Antasari yaitu 75. Selain nilai yang masih kurang dari KKM hanya terdapat beberapa siswa saja yang mampu dan menyukai pembelajaran menulis puisi. Lemahnya kemampuan menulis puisi peserta didik ada pada proses menentukan judul, mengembangkan tema, serta dalam menentukan diksi atau pemilihan kata. Selain itu, peserta didik juga kurang tertarik dalam kegiatan pembelajaran menulis puisi lama dikarenakan pembelajaran yang terjadi sangat monoton. Hal tersebut juga disebabkan oleh kurangnya minat peserta didik dalam mengikuti pembelajaran. Berdasarkan permasalahan tersebut, penelitian ini dimaksudkan untuk perbaikan pembelajaran keterampilan menulis puisi. Jadi, solusi yang diberikan dalam penelitian ini berkenaan dengan menulis puisi adalah dengan menggunakan media audio visual yang diharapkan dapat meningkatkan kemampuan menulis puisi lama pada peserta didik kelas VIII-1 SMP Pangeran Antasari.

Pembelajaran menulis puisi masih diarahkan pada hal-hal teknis belaka atau setidaknya masih berkutat pada masalah pemahaman teks puisi tersebut. Padahal strategi demikian sesungguhnya hanya akan semakin menjauhkan peserta didik dari hakekat puisi itu sendiri. Pembelajaran seperti itu juga akan terkesan kering dan hanya menyentuh pada aspek kognitif saja. Pembelajaran menulis puisi tidak semata-mata bertujuan untuk mendidik atau mencetak peserta didik menjadi sastrawan, melainkan lebih ke arah pengalaman menulis puisi. Dengan bekal menulis tersebut, pendidik akan membawa peserta didik untuk memupuk minat, menghargai, dan selanjutnya memiliki selera positif terhadap puisi. Pada kenyataanya masih banyak pendidik hanya memberi peserta didiknya dengan teori-teori tentang puisi, akibatnya pembelajaran menulis puisi menjadi kegiatan belajar mengajar yang membosankan. Proses pemunculan ide sampai penulisan puisi disebut proses kreatif yang akan menjadi bekal peserta didik dalam kehidupannya kelak. Karena puisi adalah karya sastra yang mengandung nilai-nilai moral yang sangat dibutuhkan oleh anak bangsa Indonesia.

Media pembelajaran audio visual merupakan media pembelajaran yang pada dasarnya mengandung komponen (unsur) berupa visual (pemandangan/ gambar/ dilihat) dan audio (suara/ didengar). Media pembelajaran audio visual adalah perantara atau penyampaian pesan pembelajaran yang mengandung komponen gambar dan suara, karena menggunakan lebih dari satu panca indra dalam pemanfaatannya. Perkembangan zaman telah membawa revolusi besar dalam pengembangan media pembelajaran yang digunakan di kelas-kelas. Beragam produk digital telah memperkaya dan memfungsikan media pembelajaran lebih dari sebelumnya. Sekarang ini sangat sangat mudah kita temui dan bahkan dibuat langsung oleh guru, beragam media pembelajaran audio visual modern untuk digunakan bersama-sama alat elektronik seperti CD ROM (Disk-Read Only Memory), DVD (Digital Video Disc), audio book, video klip, dan CD (DiskRead) Musical. Media-media pembelajaraan berbasis website dan software (perangkat lunak) pun merambah masuk ke kelas-kelas untuk memaksimalkan pembelajaran. 
Pembelajaran menulis puisi menggunakan audio visual mempunyai tujuan untuk menyiapkan peserta didik berdasarkan Standar Nasional Pendidikan (SNP) Indonesia yang tarafnya internasional sehingga lulusannya memiliki wawasan dan kemampuan daya saing internasional. Dengan demikian, pembelajaran menulis puisi menggunakan audio visual mempengaruhi komponenkomponen pembelajaran menulis puisi yang meliputi guru, siswa, tujuan, materi, pembelajaran dan evaluasi. Oleh karena itu, pembelajaran menulis puisi menggunakan audio visual sebagai program terobosan dalam upaya untuk meningkatkan kualitas pendidikan perlu diteliti untuk memberikan perkembangan baru dalam pembelajaran puisi lama di SMP Pangeran Antasari Medan.

Dalam menulis puisi menggunakan audio visual siswa harus mampu mengapresiasi puisi tersebut sampai menghasilkan karya sastra (puisi) yaitu berupa teks puisi. Selain itu, media audio visual merupakan salah satu langkah baru untuk meningkatkan kualitas pendidikan Indonesia. Oleh karena itu, pembelajaran menulis puisi menggunakan media audio visual (video) di kelas VIII-1 SMP Swasta Pangeran Antasari merupakan hal yang menarik dan sangat penting.

\section{B. Metode Penelitian}

Penelitian ini menggunakan metode penelitian tindakan kelas (Classrom Action Research) atau biasa disebut PTK. Penelitian tindakan kelas adalah kegiatan mencermati sekelompok peserta didik yang sedang melakukan proses belajar dengan suatu cara tertentu dengan tujuan meningkatkan hasil belajar peserta didik menjadi lebih memuaskan.

Penelitian tindakan kelas merupakan salah satu cara untuk memperbaiki dan meningkatkan layanan pendidik yang diselenggarakan dalam peningkatan kualitas program sekolah secara keseluruhan.

Pada penelitian ini peneliti menerapkan desain model PTK dari Kennis dan Mc Taggart, Tiap siklus terdiri atas empat tahap, yaitu; (1) perencanaan, (2) pelaksanaan, (3) pengamatan, dan (4) refleksi. Jika tindakan siklus I rata-rata nilai peserta didik belum mencapai target yang telah ditentukan, maka akan dilakukan tindakan siklus II.

\section{Hasil dan Pembahasan}

Hasil tes terbagi atas tiga bagian yaitu prasiklus, siklus I dan siklus II. Prasiklus adalah kemampuan menulis puisi lama siswa sebelum dilakukan tidakan dengan hasil belum sangat memuaskan karena masih dalam kategori sangat tidak baik. Siklus I adalah kemampuan menulis puisi lama siswa setelah adanya tindakan dengan media audio visual dengan tema keadaan sekitar, namun masih dalam kategori cukup baik, dan siklus II adalah hasil menulis puisi lama siswa dengan telah dilakukannya tindakan yang berbeda dari siklus I yaitu mengganti tema video dan cara proses pembelajarannya, dengan kategori sangat baik.

Prasiklus merupakan kondisi pembelajaran menulis puisi lama sebelum peserta didik diberi perlakuan atau tindakan, hanya berupa memberikan tes awal dengan konisi alami siswa. Untuk mengetahui hasil prasiklus, peserta didik diberi lembar kerja yang berisi perintah untuk menulis puisi berkenaan dengan tema bebas sesuai pemikiran peserta didik. Berdasarkan hasil perolehan nilai prasiklus (lampiran 4), maka kemampuan menulis puisi lama kelas VIII-1 mencapai rata-rata secara klasikal 33.6 dengan kategori sangat tidak baik. Hasil pembelajaran 
menulis puisi lama pada prasiklus hanya berupa tes, berikut rangkuman nilai siswa pada prasiklus.

Tabel 4.1 Perolehan Nilai Prasiklus

\begin{tabular}{|l|l|c|c|c|}
\hline No & Kategori & $\begin{array}{l}\text { Rentang } \\
\text { Nilai }\end{array}$ & $\begin{array}{l}\text { Freku } \\
\text { ensi }\end{array}$ & $\begin{array}{c}\text { Persentase } \\
(\%)\end{array}$ \\
\hline 1 & $\begin{array}{l}\text { Sangat } \\
\text { tidak } \\
\text { baik }\end{array}$ & $0-39$ & 17 & 64 \\
\hline 2 & $\begin{array}{l}\text { Tidak } \\
\text { baik }\end{array}$ & $40-54$ & 6 & 28 \\
\hline 3 & $\begin{array}{l}\text { Cukup } \\
\text { baik }\end{array}$ & $55-69$ & 1 & 4 \\
\hline 4 & Baik & $70-84$ & 1 & 4 \\
\hline 5 & $\begin{array}{l}\text { Sangat } \\
\text { baik }\end{array}$ & $85-100$ & - & - \\
\hline \multicolumn{7}{|c|}{ jumlah } & 25 & 100 \\
\hline
\end{tabular}

Data pada tabel 4.1 menunjukkan hasil skor dan nilai kelas tes prasiklus kemampuan peserta didik kelas VIII-1 SMP Pangeran Antasari dalam menulis puisi lama masih tergolong sangat tidak baik. Ketujuh aspek yang dinilai yaitu diksi, bahasa kias, pencitraan, persajakan, tema, nada, suasana, perasaan, dan amanat. Dalam prasiklus yang telah dilakukan hanya terdapat satu peserta didik dari 25 peserta didik yang mendapat nilai lebih dari KKM dengan persentasi 4\%. Rata-rata nilai kelas tes prasiklus pembelajaran menulis puisi lama pada peserta didik kelas VIII-1 SMP Pangeran Antasari mencapai rata-rata $33.6 \%$ atau berkategori sangat tidak baik.

\section{Tabel 4.2 Skor Kemampuan Menulis} Puisi Lama Pada

\section{Masing-masing Aspek}

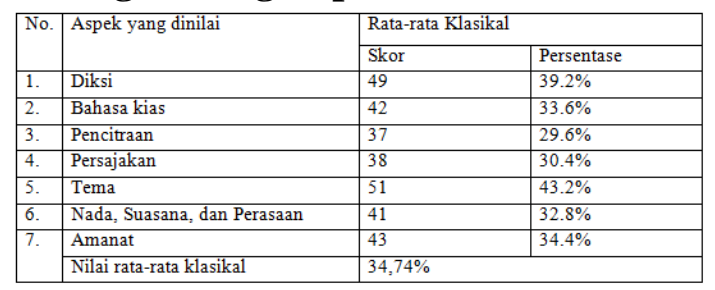

Tidak hanya dari nilai KKM, nilai dari masing-masing aspek dari tabel 4.2 terlihat bahwa persentasi diksi hanya $39.2 \%$ dalam kategori sangat tidak baik, bahasa kias $33.6 \%$ kategori sangat tidak baik, pencitraan $29.6 \%$ kategori sangat tidak baik, persajakan $30.4 \%$ kategori sangat tidak baik, tema $43.2 \%$ kategori tidak baik, nada, suasana, dan perasaan 32.8 katerori sangat tidak baik, dan amanat $34.4 \%$ kategori sangat tidak baik. Dari seluruh aspek yang dinilai hanya tema yang mendapat persentase tertinggui dengan persentase $43.2 \%$ dengan kategori tidak baik. Dan dari hasil perhitungan nilai ratarata keseluruhan aspek diperoleh persentase sebesar $34.74 \%$ atau kategori sangat tidak baik. Dengan demikian harus dilakukan siklus lanjutan yaitu siklu I untuk memperoleh nilai yang lebih baik dari prasiklus tersebut.

\section{Hasil Penelitian Siklus I}

Hasil tes pada siklus I merupakan awal diterapkannya pembelajaran kemampuan menulis puisi lama menggunakan media audio visual. Sebelum dilakukan tindakan suklus I terdapat hasil dari tes prasiklus yang terlihat nilai pada ketujuh aspek yang masih sangat rendah. Dengan masalah tersebut dilakukanlah tindakan dengan menggunakan media audio visual yang akan membuat siswa menjiwai puisi yang ditulis dan dapat membuat nilai meningkat dari hasil prasiklus. Secara umum, hasil tes kemampuan menulis puisi menggunakan media audio visual dapat dilihat pada tabel berikut:

Tabel 4.3 Perolehan Nilai Siklus I

\begin{tabular}{|c|c|c|c|c|}
\hline No & Kategori & $\begin{array}{c}\text { Rentang } \\
\text { Nilai }\end{array}$ & Frekuensi & $\begin{array}{c}\text { Persentase } \\
(\%)\end{array}$ \\
\hline 1 & $\begin{array}{l}\text { Sangat } \\
\text { tidak } \\
\text { baik }\end{array}$ & $0-39$ & 3 & 12 \\
\hline 2 & $\begin{array}{l}\text { Tidak } \\
\text { baik }\end{array}$ & $40-54$ & 2 & 8 \\
\hline 3 & $\begin{array}{l}\text { Cukup } \\
\text { baik }\end{array}$ & $55-69$ & 11 & 44 \\
\hline 4 & Baik & $70-84$ & 6 & 24 \\
\hline 5 & $\begin{array}{l}\text { Sangat } \\
\text { baik }\end{array}$ & $85-100$ & 3 & 12 \\
\hline \multicolumn{3}{|c|}{ jumlah } & 25 & 100 \\
\hline
\end{tabular}


Data pada tabel 4.3 menunjukan beberapa ketuntasan dalam kompetensi menulis puisi lama dengan menggunakan media audio visual. Tabel tersebut menunjukan bahwa hasil tes kompetensi menulis puisi lama siswa secara klasikal mencapai total nilai 1608 dengan rata-rata 64,3 dalam kategori cukup baik.

Kelas VIII-1 berjumlah 25 siswa, yang memperoleh nilai dalam kategori tuntas KKM sebanyak 7 siswa. Siswa dengan kategori sangat tidak baik sebanyak 3 siswa atau sebesar $12 \%$ dengan rengtang nilai 0 - 39, kategori tidak baik sebanyak 2 siswa atau sebesar $8 \%$ dengan rentang nilai 40 - 54, kategori cukup baik sebanyak 11 siswa atau sebesar $44 \%$ dengan rentang nilai $55-69$, kategori baik sebanyak 6 siswa atau sebesar 24\% dengan rentang nilai $70-84$, dan kategori sangat baik sebanyak 3 siswa atau $8 \%$ dengan rentang nilai $85-100$.

Hasil tes yang didapat dari siklus I masih rendah karena hanya terdapat 7 siswa yang mendapatkan nilai dari KKM yang telah ditetapkan. Hal ini disebabkan karena pembelajaran menulis puisi lama adalah hal baru bagi peserta didik. Sihingga mempengaruhi antusias siswa dalam menerima pelajaran. Proses pembelajaran seperti ini merupakan proses awal bagi siswa untuk menyesuaikan diri dalam belajar menulis puisi lama. Nilai siklus I diperoleh dari penjumlahan skor dari 7 aspek kemampuan menulis puisi lama.

\section{Hasil Penelitian Siklus II}

Pembelajaran kemampuan menulis puisi lama pada siklus II ini merupakan perbaikan dan pemecah masalah yang dihadapi pada siklus I. pada siklus II ini diuraikan tentang pelaksanaan pembelajaran menulis puisi lama dengan menggunakan media audio visual terdiri atas data tes dan nontes.

\section{Hasil Tes Kemampuan Menulis Puisi Lama Siklus II}

Hasil nilai pada siklus I masih belum memuaskan karena hanya 7 siswa yang lulus dari nilai KKM, dengan begitu dilakukanlah tindakan siklus II untuk memperbaiki nilai siswa uang belum memenuhi KKM dengan tidakan yang ditambahkan pada pembelajaran menulis puisi lama dengan menggunakan media audio visual. Hasil kemampuan menulis puisi lama dengan menggunakan media audio visual pada siklus II dapat dilihat pada tabel berikut:

\section{Perolehan Nilai Siklus II}

\begin{tabular}{|c|c|c|c|c|}
\hline No & Kategori & $\begin{array}{c}\text { Rentang } \\
\text { Nilai }\end{array}$ & Frekuensi & $\begin{array}{c}\text { Persentase } \\
(\%)\end{array}$ \\
\hline 1 & $\begin{array}{c}\text { Sangat } \\
\text { tidak } \\
\text { baik }\end{array}$ & $0-39$ & - & - \\
\hline 2 & $\begin{array}{c}\text { Tidak } \\
\text { baik }\end{array}$ & $40-54$ & - & - \\
\hline 3 & $\begin{array}{c}\text { Cukup } \\
\text { baik }\end{array}$ & $55-69$ & 2 & $8 \%$ \\
\hline 4 & Baik & $70-84$ & 14 & $56 \%$ \\
\hline 5 & $\begin{array}{c}\text { Sangat } \\
\text { baik }\end{array}$ & $85-100$ & 9 & $36 \%$ \\
\hline \multicolumn{3}{|c|}{ jumlah } & 25 & $100 \%$ \\
\hline
\end{tabular}

Data pada tabel 4.14 menunjukkan beberapa ketuntasan hasil belajar siswa dalam kemampuan menulis puisi lama menggunakan media audio visual. Ketuntasan siswa mencapai 92\%. Sejumlah 23 siswa sudah mencapai batas minimal KKM. Tabel tersebut menunjukkan bahwa hasil tes kompetensi menulis puisi siswa secara klasikal mencapai total nilai 2067 dengan rata-rata $82.68 \%$ dengan kategori baik. Kelas VIII-1 berjumlah 25 siswa, yang memperoleh nilai dalam kategori sangat baik dengan rentang nilai 85-100 ada 9 siswa. Kategori baik sebanyak 14 siswa dengan rentang nilai 70-84, dan Kategori cukup baik sebanyak 2 siswa dengan rentang nilai 5569. 
Pembahasan dalam penelitian ini berdasarkan hasil penelitian selama dua siklus yaitu siklus I dan siklus II. Pembahasan hasil dua siklus itu meliputi hasil tes dan nontes. Kegiatan pembelajaran siklus I diawali dengan guru memberikan apersepsi pembelajaran menulis puisi. Siswa terlihat lebih bersemangat dan antusias, melalui kegiatan ini siswa menjadi tahu apa manfaat dan tujuan yang hendak dicapai dalam pembelajaran menulis puisi lama.

Kegiatan inti diawali dengan guru memberikan materi menulis puisi lama dan memberikan penjelasan dalam proses menulis puisi lama. Pada saat kegiatan ini siswa memperhatikan contoh puisi yang dicontohkan guru di depan kelas. Ketika siswa memperhatikan penjelasan guru, masih terdapat siswa yang berbicara sendiri dan bermalas-malasan Kegiatan selanjutnya yaitu siswa memperhatikan media audio visual yang ditayangkan oleh guru. Siswa secara fokus memperhatikan tayangan video yang akan menjadi inspirasi puisi yang mereka buat.

Pada saat menulis puisi masih terdapat beberapa siswa yang terlihat bingung untuk menggabungkan kata-kata dalam proses menulis puisi lama tetapi mereka tidak berani bertanya kepada. Setelah semua siswa telah menyelesaikan menulis puisi, siswa membacakan puisinya di depan kelas. Siswa yang maju ke depan kelas masih terlihat malu dan suaranya saat membaca masih kecil. Siswa yang aktif dalam pembelajaran diberikan penghargaan oleh guru. Kegiatan terakhir pada siklus I yang dilakukan adalah pembahasan dan refleksi bersama.

Rangkaian pada siklus I juga diterapkan pada pembelajaran siklus II hanya yang membedakan yaitu, pada saat siklus I guru tidak menyuru siswa membawa buku yang berhubungan dengan puisi lama serta tidak ada diskusi dengan teman sebangku. Di siklus II siswa disuru membawa buku yang berhubungan dengan puisi lama serta memberikan waktu kepada mereka untuk berdiskusi sesama teman sebangku setelah tayangan video ditayangkan. Pada saat siklus II siswa terlihat lebih bersemangat dan antusias dalam mendengarkan penjelasan guru. Siswa sudah mulai tertarik dengan materi pembelajaran. Pada saat kegiatan siswa mengamati tayangan video, siswa terlihat lebih berkonsentrasi karena video yang ditayangkan berbeda dan lebih menyentuh. Kemudian saat proses menulis puisi siswa mampu menulis puisi dengan baik. Siswa berani bertanya langsung kepada guru tentang kesulitan yang dialami sehingga guru langsung memberikan solusi kepada siswa yang merasa kesulitan.

Aspek-aspek yang dinilai dalam kemampuan menulis puisi meliputi 7 aspek yaitu: 1. Diksi, 2. Bahasa kias, 3. Pencitraan, 4. Persajakan, 5. Tema, 6. Nada,suasana, dan perasaan, 7. Amanat. Nilai prasiklus, siklus I, dan siklus II diperoleh dari penjumlahan skor dari 7 aspek kemampuan menulis puisi lama. Hasil setiap siklusnya dapat dilihat sebagai berikut:

Tabel 4.25 Data Hasil Tes Masingmasing Aspek Menulis Puisi Lama

\begin{tabular}{|c|c|c|c|c|}
\hline \multirow[t]{2}{*}{ No. } & \multirow[t]{2}{*}{ Aspek / Indikator Yang Dinilai } & \multicolumn{3}{|c|}{$\%$ Hasil Tes } \\
\hline & & Prasiklus & Siklus I & Siklus II \\
\hline 1. & Diksi & $39.2 \%$ & $62.4 \%$ & $72 \%$ \\
\hline 2. & Bahasa Kias & $33.6 \%$ & $61.6 \%$ & $77.6 \%$ \\
\hline 3. & Pencitraan & $33.6 \%$ & $62.4 \%$ & $79.2 \%$ \\
\hline 4. & $\begin{array}{l}\text { Persajakan } \\
\end{array}$ & $30.4 \%$ & $64 \%$ & $81.6 \%$ \\
\hline 5. & Tema & $40.8 \%$ & $68 \%$ & $97.6 \%$ \\
\hline 6. & Nada, Suasana, dan Perasaan & $32 \%$ & $70.4 \%$ & $77.6 \%$ \\
\hline 7. & Amanat & $36 \%$ & $66.4 \%$ & $97.6 \%$ \\
\hline \multicolumn{2}{|c|}{ Rata-rata } & $35.09 \%$ & 64.40 & $85 \%$ \\
\hline
\end{tabular}

Hasil dari tabel tersebut menunjukan perbedaan antar siklus dari ketujuh aspek dalam penulisan puisi lama. Diksi prasiklus $39.2 \%$, siklus I $62.4 \%$ dan siklus II $77.6 \%$. Bahasa kias prasiklus $33.6 \%$, siklus I $61.6 \%$, siklus II 77 . Pencitraan 
prasiklus 33.6, siklus I 62.4, siklus II 79.2. Persajakan prasiklus $30.4 \%$, siklus I 64\%, siklus II $81.6 \%$. Tema prasiklus $40.8 \%$, siklus I 68\%, siklus II 97.6\%. Nada, suasana, dan perasaan prasiklus $32 \%$, siklus I 70.4, siklus II $77.6 \%$ dan amanat prasiklus 35.09, siklus I 64.40, siklus II 85\%. Dari rata-rata tersebut dinyatakan bahwa setiap silkus mengalami peningkatan yang sangat baik.

\section{Peningkatan Kemampuan Menulis Puisi} Lama Dengan Menggunakan Media Audio Visual

Sebelum peneliti melakukan penelitian pada kelas VIII-1 SMP Pangeran Antasari, peneliti terlebih dahulu melakukan observasi awal dan wawancara terhadap guru mata pelajaran Bahasa Indonesia kelas VIII-1. Hal ini dilakukan dengan tujuan untuk mengetahui gambaran kondisi awal siswa tentang kemampuan menulis, khususnya menulis puisi lama. Setelah dianalisis, peneliti kemudian melakukan penelitian yang dilakukan dalam dua siklus yaitu siklus I dan siklus II. Siklus II dilaksanakan apabila pada siklus I terdapat beberapa kekurangan yang dapat diketahui dari hasil tes dan nontes pada siklus I. Dari kegiatan tes dan nontes tersebut kemudian dapat disimpulkan kegiatan apa saja yang harus dilakukan untuk memperbaiki pembelajaran pada siklus selanjutnya. Peneliti menggunakan media audio visual untuk meningkatkan kemampuan menulis puisi lama siswa kelas VIII-1 SMP Pangeran Antasari.

Pada kegiatan pembelajaran siklus I dan siklus II diawali dengan apersepsi yang dilakukan oleh guru. Hal ini dilakukan untuk menciptakan kondisi yang baik untuk pembelajaran. Setelah apersepsi, guru menjelaskan materi dengan menunjukkan contoh puisi lama. Kegiatan selanjutnya menulis puisi, Setelah semua siswa selesai menulis puisi, hasil puisi siswa dibacakan di depan kelas. Hasil tes menulis puisi lama pada siklus I dan siklus II dapat dilihat pada tabel sebagai berikut:

Tabel 4.28 Hasil Tes Kemampuan Menulis Puisi Lama Siklus I dan Siklus II

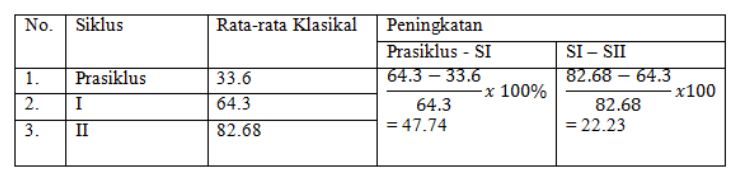

Dari tabel tersebut prasiklus dengan rata-rata 33.6, siklus I 64.3, dan siklus II 82.68. Diperoleh peningkatan prasiklus kurang siklus I diperoleh peningkatan sebesar 47.744 dan siklus I kurang siklus II sebesar 22.230. Berikut merupakan diagram yang menunjukan peningkatan hasil tes prasiklus, siklus I ke siklus II.

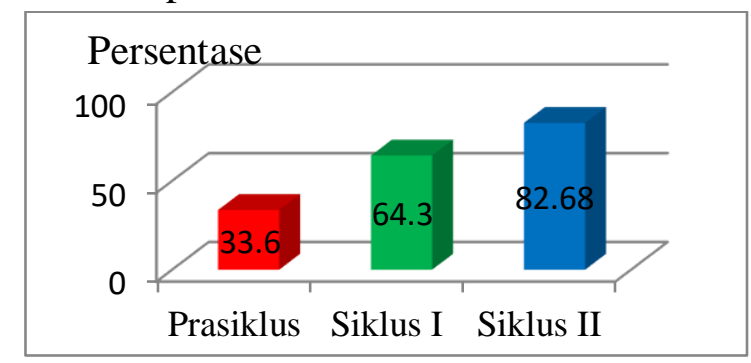

Grafik 4.20 Peningkatan Kemampuan Menulis Puisi Lama

Prasiklus, Siklus I, dan Siklus II

Berdasarkan diagram tersebut dapat diketahui adanya peningkatan hasil tes kemampuan menulis puisi lama yang dicapai siswa pada prasiklus, siklus I dan siklus II. Nilai prasiklus mencapai $33.6 \%$ dan hanya satu siswa yang mendapatkan nilai KKM atau sebesar 4\%. Karena belom ada tindakan dalam penelitian prasiklus, pada siklus I mencapai $64,3 \%$ dan terdapat tujuh siswa yang mendapat nilai KKM dengan persentase sebesar 28\%. Keadaan tersebut disebabkan karena siswa banyak mengalami kesulitan dalam pemilihan kata yang tepat untuk menulis puisi lama. Pada siklus II siswa mengalami peningkatan 
BIP: Jurnal Bahasa Indonesia Prima

Vol. 3, No. 2, 2021, September 2021, PP.

rata-rata mencapai $82.68 \%$ yaitu terdapat 23 siswa yang mendapatkan nilai KKM dan lebih dari KKM dengan persentase 92\%. Terjadi peningkatan sebanyak 22.23. Hal itu terjadi karena pada saat kegiatan pembelajaran peneliti memberikan pembelajaran semakin intensif melalui pendekatan komunikatif sehingga pembelajaran menyenangkan dan tidak membosankan. Materi yang diajarkan mudah dipahami oleh siswa dan nilai ketuntasan klasikal pada siklus II mencapai $92 \%$ atau dalam kategori sangat baik.

Tabel 4.29 Data Hasil Ketentuan Belajar Klasikal

\begin{tabular}{|l|l|l|}
\hline No. & Siklus & Kuantitasan \\
\hline 1. & Prasiklus & $1: 25 \times 100 \%=4 \%$ \\
\hline 2. & Siklus I & $7: 25 \times 100 \%=28 \%$ \\
\hline 3. & Siklus II & $23: 25 \times 100 \%=92 \%$ \\
\hline
\end{tabular}

Pada tabel 4.29 terlihat bahwa hasil pada prasiklus yang mendapatkan nilai sesuai KKM hanya terdapat 1 siswa dan yang tidak tuntas mecapai 24 siswa, siklus I yang mendapatkan milai sesuai KKM 7 siswa dan yang tidak tuntas 18 siswa, sedangkan pada siklus II yang tuntas sesuai KKM sebesar 23 siswa dan yang tidak tuntas hanya 2 siswa. Dengan ketentuan belajar klasikal dinyatakan berhasil setelah nilai setiap siswa harus mencapai KKM dengan perhitungan klasikal $\geq 85 \%$. Dengan demikian dalam penelitian ini dinyatakan ada peningkatan yaitu nilai sebesar $92 \%$ dan terdapat peningkatan dari prasiklus, siklus I, dan siklus II.

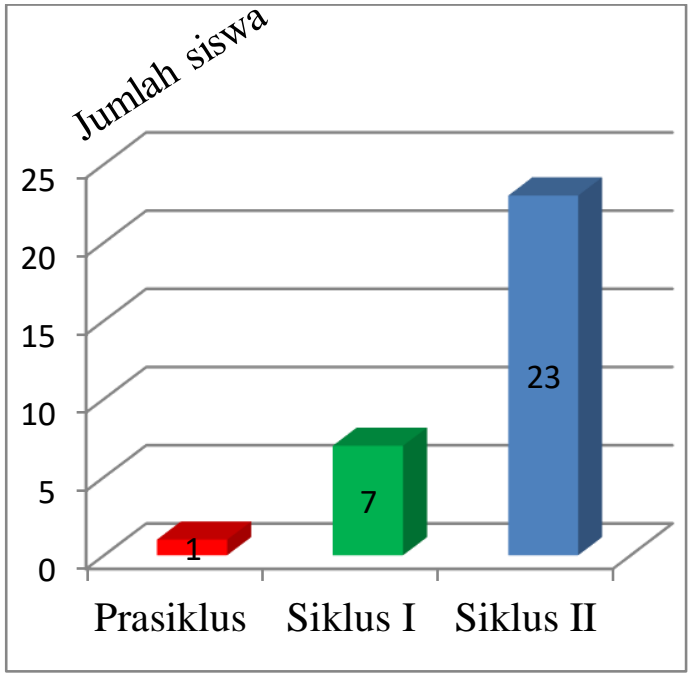

4.21 Grafik Hasil Ketentuan Belajar Klasikal

Kesimpulan

Berdasarkan hasil penelitian dan pembahasan pembelajaran peningkatan kemampuan menulis puisi lama menggunakan media audio visual pada peserta didik kelas VIII-1 SMP Pangeran Antasari, dipaparkan sebagai berikut:

1. Proses pembelajaran kemampuan menulis puisi lama menggunakan media audio visual berjalan dengan lancar. Pada awal pembelajaran siklus I peserta didik masih banyak yang tidak mengerti menulis puisi lama. Sebagian peserta didik juga masih ada kurang memperhatikan penjelasan dari guru serta ada sebagian peserta didik yang malasmalasan mengerjakan tugas yang diberikan oleh guru. Berbeda pada pembelajaran siklus I, pada proses pembelajaran menulis puisi lama menggunakan media audio visual siklus II, peserta didik menunjukkan perkembangan kearah yang lebih positif. Peserta didik yang pada pembelajaran siklus I masih malu dan canggung dengan guru, pada pembelajaran siklus II sudah mulai aktif bertanya jawab dengan guru. 
Sebagian besar peserta didik juga sudah memperhatikan penjelasan yang diberikan oleh guru, serta lebih serius mengerjakan tugas yang diberikan oleh guru.

2. Peningkatan kemampuan menulis puisi lama menggunakan media audio visual tampak pada hasil tes dan nontes. Rata-rata nilai kelas pada prasiklus sebelum dilakukan tindakan hanya bersifat alami sebesar 33.6 atau kategori sangat tidak baik dan hanya 1 siswa yang lulus KKM atau sebesar $4 \%$. Sementara itu, ratarata nilai kelas pada siklus I sebesar 64.3 atau kategori cukup baik dan terdapat 7 siswa yang lulus KKM atau sebesar 28\%. Hal ini menunjukkan adanya peningkatan rata-rata nilai kelas sebesar $30.7 \%$ dari prasiklus yang hanya mencapai rata-rata nilai kelas 33.6, pada siklus I naik menjadi 64.3. Pada siklus II rata-rata nilai kelas meningkat sebesar $18.38 \%$ menjadi 82.68 dan terdapat 23 siswa yang lulus KKM atau sebesar 92\% dengan kategori baik. Dari siklus I yang hanya mencapai rata-rata nilai kelas sebesar 64.3. Peningkatan rata-rata nilai kelas dari prasiklus ke sikllus II yaitu sebesar $49.08 \%$, dari prasiklus yang hanya mencapai rata-rata nilai kelas 33.6, pada siklus II meningkat menjadi 82.68 .

3. Perilaku peserta didik kelas VIII-1 SMP Pangeran Antasari juga mengalami perubahan ke arah yang lebih positif setelah mengikuti pembelajaran menulis puisi menggunakan media audio visual. Selain mengalami peningkatan pada rata-rata nilai kelas dan nilai rata-rata skor setiap aspek dalam menulis puisi lama, peserta didik juga mengalami perubahan perilaku belajar. Hal tersebut dapat diketahui berdasarkan hasil observasi, angket, pedoman wawancara, dan dokumentasi. Pada pembelajaran siklus I sebagian besar peserta didik masih malu dan canggung. Mereka juga ada yang masih bercanda sendiri, kurang bertanggung jawab dalam melaksanakan tugasnya, kurang aktif bertanya, dan sebagainya. Perilaku-perilaku tersebut dapat dikurangi pada pembelajaran siklus II. Peserta didik banyak yang menunjukan perubahan kearah positif terhadap pembelajaran menulis puisi lama dengan menggunakan media audio visual.

a) Dari hasil penelitian dan kesimpulan yang telah dipaparkan, maka peneliti mengajukan beberapa saran sebagai berikut: Guru dapat menerapkan media audio visual dalam pembelajaran menulis puisi lama agar lebih meningkatkan kualitas dan kemampuan siswa meningkat

b) Kemampuan siswa dalam menulis puisi lama perlu ditingkatkan lagi. Hal tersebut tentunya memerlukan media pembelajaran yang lebih efektif digunakan dalam proses belajar mengajar (PBM) di sekolah. Salah satunya adalah media audio visual.

c) Disarankan agar penelitian selanjutnya tetap memperhatikan perkembangan media pembelajaran yang digunakan di sekolah khususnya dalam pembelajaran menulis puisi lama. 
BIP: Jurnal Bahasa Indonesia Prima Vol. 3, No. 2, 2021, September 2021, PP.

\section{Daftar Pustaka}

Achmad, Sri Winata. 2015. Panduan Lengkap Menjadi Penulis Handal. Yokyakarta: Aksara.

Aji, Aminudin Winahyu. 2013. "Peningkatan Kemampuan Menulis Puisi Dengan Menggunakan Media Audio Visual Pada Siswa Kelas X1 SMA Negeri 1 Sambi”. Skripsi: Fakultas Keguruan dan Ilmu Pendidikan. Universitas Muhammadiyah Surakarta.

Ambarita, B. 1992. Puisi Dan Gaya Bahasa. Medan: Falkutas Pendidikan Bahasa Dan Seni.

Arikunto, Suharsimi dkk. 2010. Penelitian Tindakan Kelas. Jakarta : Bumi Aksara.

2007. Dasar-dasar Evaluasi Pendidikan. Jakarta: Bumi Aksara.

Auliani, Rizkia. 2015. "Peningkatan Kemampuan Menulis Teks Berita Dengan Menggunakan Media Audio Visual Siswa Kelas VIII Semester II SMPN 2 Tanggerang Selatan”. Skripsi: Fakultas Ilmu Tarbiyah dan Keguruan. Universitas Syarif Hadayatullah Jakarta.

Arum, Fransiska Puspita. 2009. "Peningkatan Keterampilan Menulis Cerpen Menggunakan Teknik Fastwriting Melalui Media Audio Visual Siswa Kelas X-4 SMA Kesatrian Semarang". Skripsi Fakultas Bahasa Dan Seni. Universitas Negeri Semarang.
Arsyad, Azhar. 2011. Media Pembelajaran. Jakarta: PT RajaGrafindo Persada.

2013. Media Pembelajaran. Jakarta: PT RajaGrafindo Persada.

Dalman. 2014. Keterampilan Menulis. Jakarta: RajaGrafindo Persada.

Daryanto. 2016. Media Pembelajaran. Yogyakarta: Gava Media.

Depdiknas. 1992. Kamus Besar Bahasa Indonesia Edisi Pertama. Jakarta: Balai Pustaka.

Dianawati, Ajen. 2016. Super Lengkap Pribahasa Indonesia Plus Puisi \& Pantun. Jakarta: Wahyu Media.

Djamarah, S. B. dan Aswan Zain. 2010. Strategi Belajar Mengajar. Jakarta: Rineka Cipta.

Ganie, Tajuddin Noor. 2015. Buku Bahasa Indonesia. Yogyakarta: Araska.

Hayati, A dan Winarno Adiwardoyo. 1990. Latihan Apresiasi Sastra. Malang: Y A 3 Malang.

Isneni, Yuni Nur. 2012. "Upaya Meningkatkan Kemampuan Menulis Puisi Dengan Menggunakan Media Permainan Kata Pada Siswa Kelas VIII C SMP Negeri 2 Kesesi Kabupaten Pekalongan Jawa Tengah". Skripsi Fakultas Bahasa Dan Seni. Universitas Negeri Yogyakarta. 
BIP: Jurnal Bahasa Indonesia Prima Vol. 3, No. 2, 2021, September 2021, PP.

Keraf, Gorys. 2006. Diksi Dan Gaya Bahasa. Jakarta: PT Gramedia Pustaka Utama.

Luxemburg, Jan Van dkk. 1992. Pengantar Ilmu Sastra. Jakarta: PT Gramedia.

Sudjana, Nana. (1992). Penilaian Hasil Proses Belajar Mengajar. Bandung: Remaja Rosdakarya.

Susmita, Nelvia. 2012. "Peningkatan Kemampuan Menulis Deskripsi Dengan Menggunakan Media Audio Visual Pada Siswa Kelas X SMK PI Ambarukmo 1". Skripsi Fakultas Bahasa Dan Seni. Universitas Negeri Yogyakarya.
Pradopo, Rachmat Djoko. 1990. Pengkajian Puisi. Yogyakarta: Gadjah Mada University Press.

Purwanto, Ngalim. 2004. Prinsip-prinsip dan Teknik Evaluasi Pengajaran. Bandung: PT Remaja Rosdakarya.

Rahmawati, Fitri. 2014. Jurus Kilat Menguasai Sastra Indonesia. Jakarta: Laskar Aksara.

Waluyo, Herman J. 2005. Apresiasi Puisi. Jakarta: PT Gramedia Pustaka Utama.

Wasrie, Kusnadi. 2014. Buku Pintar Bahasa \& Sastra Indonesia. Solo: Lingkar Media. 